\title{
Sezen Aksu'nun Şiirlerinde Türk Edebiyatının İzleri
}

\author{
Öğr. Gör. Dr. Derya Kılıçkaya ${ }^{1^{*}}$
}

Gelis tarihi: 24.12.2020

Kabul tarihi: 22.01.2020

\section{Atuf bilgisi: \\ IBAD Sosyal Bilimler Dergisi \\ Sayı: $6 \quad$ Sayfa: 296-320 \\ Yıl: 2020 Dönem: Kış}

This article was checked by iThenticate. Similarity Index 5\%

Bu makalede araştırma ve yayın etiğine uyulmuştur.

\section{Kocaeli Üniversitesi, Türkiye, derya.kilickaya@kocaeli.edu.tr}

ORCID ID 0000-0001-5964-5485

\section{* Sorumlu yazar}

ÖZ

Sezen Aksu, müziğe başladığı 1970'lerden günümüze değin, sesi ve yorumuyla Türk pop müziğindeki yerini korumayı başarmıştır. Başka söz yazarlarının yazdığ şarkıları da seslendirmekle birlikte, çoğunlukla kendi yazdığ 1 şarkıları söylemiştir. $\mathrm{Bu}$ şarkılardaki sözler incelendiğinde onların boş birer laftan ibaret olmadığı, yaşanmışlıkların üzerine kaleme alındığı söylenebilir. Dolayısıyla bu sözler, başarılı bestelerle de bir araya gelince insanları etkilemiş ve yıllar yılı dillerde dolaşmıştır. Böylelikle sanatçı, içten sözleriyle Türk halkının sevgisini kazanmayı başarmıştır. Aslında Sezen Aksu'nun yazdığı bu sözler basit bir şarkı sözünden daha da ötedir. Bunları birer şiir olarak değerlendirmek çok daha doğru olacaktır. Bütün şark sözlerini Eksik Şiir ve Eksik Şiir İkinci Kitap adıla bir araya getirmiştir. Kitaplardaki şiirler bir edebiyat araştırmacısı gözüyle okunduğunda aslında sanatçının Türk edebiyatından ne kadar çok beslendiği anlaşılır. Onun pek çok şiirinde divan ve halk şiirinin izlerini bulmak mümkündür. Sadece bunlar değil, aynı zamanda Cumhuriyet Dönemi ve sonrasındaki Türk edebiyatından da belirtiler bulunabilir. İşte bu çalışmada, Sezen Aksu'nun şiirlerindeki Türk edebiyatı izleri araştırılmış ve ortaya konmuştur. Onun şiirleri, Türk edebiyatındaki konu, mazmun, tür, üslûp ve göndermeler bakımından ele alınmıştır.

Anahtar Kelimeler: Sezen Aksu, Eksik Şiir, Türk Edebiyatı. 


\title{
Effect of Turkish Literature in Sezen Aksu's Poems
}

\author{
Dr. Lec. Derya Kılıçkaya ${ }^{1 *}$
}

First received: 24.12 .2020

Accepted: 22.01 .2020

\section{Citation:}

IBAD Journal of Social Sciences

Issue: 6

Pages: 296-320

Year: 2020

Session: Winter

This article was checked by iThenticate. Similarity Index 5\%

\author{
1 Kocaeli University Turkey, \\ derya.kilickaya@kocaeli.edu.tr \\ ORCID ID 0000-0001-5964-5485
}

\footnotetext{
* Corresponding Author
}

\begin{abstract}
Sezen Aksu has managed to maintain its place in Turkish pop music with her voice and interpretation since 1970s. She sang songs written by others and songs she wrote herself through years. When the lyrics in these songs are examined, it can be said that they are not just words, they are written on the experiences. Therefore, these words, together with successful compositions, influenced people and have been in the limelight for many years. Thus, the artist succeeds in gaining the love of the Turkish people with her sincere words. In fact, these words written by Sezen Aksu are more than a simple song. It would be more accurate to consider them as poems. She must be aware of this, bringing all his lyrics together under the name of Eksik Şiir and Eksik Şiir İkinci Kitap. When you read the poems in the books from the point of view of a literary researcher, we understand how much the artist is fed by Turkish literature. In many poems it is possible to find the effects of divan and folk poetry. Not only these, but also traces of Turkish literature in the Republican Era and beyond can be found. In this study, the traces of Turkish literature in Sezen Aksu's poems were investigated and revealed. Her poems are dealt with in terms of subject, mazmun, genre, style and references in Turkish literature.
\end{abstract}

Key Words: Sezen Aksu, Eksik Şiir, Turkish Literature. 


\section{GİRIŞ}

Fatma Sezen Yıldırım, sahne adıyla dile getirilirse Sezen Aksu, 1970’lerden günümüze kadar Türk pop müziğine yön veren önemli isimlerden biridir. Şarkı söylemenin yanı sıra söz de yazan Sezen Aksu, özellikle söz yazarı kimliği ile dikkatleri üzerine çekmiş ve dört yüzden fazla söz yazmıştır. Bunlardan yüz doksan yedisini, Aralık 2006'da Metis Yayınları Eksik Şiir adıyla yayımlamıştır. Bu kitapta, Sezen Aksu'nun bizzat kendisinin yazdığı şarkı sözleri yer alır. Mayıs 2018'de altıncı basımı yapılan kitap büyük ilgi görmüş, sanatçının sevenleri tarafından beğeniyle karşılanmıştır. Kitapta, şark1 sözleri yer alsa da her bir şarkı sözünün esasen birer şiir olduğu görülmektedir. Bir diğer ifadeyle Sezen Aksu bir şairdir. Her ne kadar kendisi 23 Nisan 2007'de bir televizyon programında, Halit Kıvanç ile yaptığı sohbet sırasında üstüne basa basa "Ben şair değilim.", "Bunlar şiir değil, bunlar şarkı sözü gerçekte.", "Ben şarkı sözü yazarıyım.", "Belki şarkı şairi olabilirim." gibi ifadeler kullansa da edebiyat araştırmacısı bakış açısıyla yaklaşıldığında ona rahatlıkla şair denebilir. Sezen Aksu'nun şair yönünü ilk dile getirenlerden biri de Mümtaz Sarıçiçek’tir. Mümtaz Sarıçiçek, Türk Dil Kurumu tarafindan yayımlanan Türk Dili Dil ve Edebiyat Dergisi'nde, Temmuz 2004'te "Şair Sezen Aksu" başlıklı bir yazı kaleme almışır. $^{2}$ Kendisi bu yazıyı kaleme aldığında henüz Sezen Aksu Eksik Şiir'i yayımlamamıştır. Buna rağmen, Aksu'daki şairlik vasfını gören Sarıçiçek, Sezen Aksu'nun albümlerinde yer alıp kendisine ait olan güfteleri bir araya getirip incelemiştir. Şairin şiirlerini önce biçim, sonra da muhteva açısından değerlendiren Sarıçiçek'in on sayfalık bu yazısı, 2018 senesinde bir kitaba dönüşecektir. "Şair Sezen Aksu: Müziğin Gölgesindeki Şiir" adıyla Kimlik Yayınlarınca yayımlanan kitap, onun şairlik yönünü daha da öne çıkarır. ${ }^{3}$

Kısacası Sezen Aksu, alelade bir şarkı sözü yazmanın ötesine giderek ortaya edebî bir metin koymuştur. Kendisi, kitabı hazırlarken çok tereddüt ettiğini ön sözde ifade eder ve eserinin adını neden Eksik Şiir koyduğunu şöyle açıklar:

"Epey bir süre çekimser kaldım. Düz düşününce zaten vardılar, ortadaydılar; müziğini çekip aldığınızda şiire ne kadar yakın durursa dursun eksik kalan o sözler bir araya toplandı̆̆ında bir bütünlük oluşturabilir miydi??"(Aksu, 2018, s. 6)

Sanatçının endişesi; müziği, melodisi çekilmiş sözlerin, okur için bir anlamı olup olmayacağıdır. Ona göre, bu hâliyle sözler eksik kalmaktadır. Evet, metinler kesinlikle şiire daha yakın dururlar; ama bu şiirlerin hep bir tarafı noksan kalır. İnsanlar, bu sözleri müzikleriyle birlikte duymaya alışmışlardır. Hâl böyleyken Sezen Aksu ve dinleyenleri için bu metinler, birer "eksik şiii" olacaktır. Sanatçı bu noktada belki de haklıdır; çünkü onun bu sözleri bize Türk edebiyatının büyük şairlerinden Ahmet Haşim'in söylediklerini hatırlatır. Haşim, Piyale mukaddimesinde manayı sıkı bir defne ormanının ortasına bırakılan bal dolu fağfur kavanoza benzetmiş ve her göze görünmeyen kelime kafilelerini, vızıltılı arılar olarak görmüştü. Bu fağfur kavanozu görmeyen okuyucunun, arıların kanat musikisini işitmekten zevk alacağını belirtmiş ve kırmızı çiçekli siyah defne ormanının; yani şiirdeki mananın bütün sırrının arıların gümüş kanatlarının sesinde olduğunu söylemiştir. Dolayısıyla Ahmet Haşim için, "şairin lisanı 'nesir' gibi anlaşılmak için değil, fakat duyulmak üzere vücud bulmuş, musiki ile söz arasında, sözden ziyade musikiye yakın mutavassit bir lisandır." (Haşim, 2004, s. 6) Sezen Aksu'nun şiirleri de tam da Ahmet Haşim'in ifade ettiği gibi musiki ile söz arasında, sözden ziyade musikiye yakın durmaktadır. Ancak bu durum, Aksu'nun metinlerini şiir olmaktan uzaklaştırmaz, aksine daha da yaklaştırır. Dolayısıyla Ahmet Haşim'in bakış açısıyla yaklaştığımızda bu metinler eksik birer şiir değil, aslında tam anlamıyla şiirdirler.

Sezen Aksu, 2016'da ikinci şiir kitabı olan Eksik Şiir İkinci Kitap'1 çıkarır. Bu kitapta 2006'dan sonra yazdığı şiirlerle birlikte, ilk kitapta gözden kaçanlar da yer almıştır. Sanatçı bu eserin ön sözünde de hayatın kendisine iç dökmenin bir yolunu bahşettiğini belirtir:

"Zaten içini dökmenin muazzam bir yolunu bahşetti bana hayat: müziği ve sözleri... Kelimelerin, kendini ifade ihtiyacının karşılanmasında çok az yer tuttuğu, insanın beden dili ve ses tonunun çok daha önemli

\footnotetext{
${ }^{1} \mathrm{https}: / /$ www.youtube.com/watch?v=8cE6UcXWJ4I

2 Sarıçiçek 2004.

${ }^{3}$ Sarıçiçek 2018.
} 
olduğu söylenir. Doğrudur, katıllyorum. Ama bu önem sırası içinde, dil kurmanın değerini teslim ederek..." (Aksu, 2016, s. 7)

Sezen Aksu, musikiye olduğu kadar kelimelere de önem vermiş ve şiirini alelade sözcüklerle yazmamıştır. Onun şiirleri okunduğunda kelime seçimine ne kadar dikkat ettiği ortaya çıkar. Özellikle gelenekten yararlanma açısından Aksu'nun yazdıkları ilgi çekicidir. Onun metinlerinde bazen divan şiirinden, bazen halk şiirinden bazen de Cumhuriyet Dönemi ve sonrasındaki Türk edebiyatından izler bulmak mümkündür. $\mathrm{Bu}$, onun Türk kültür ve edebiyatına ne kadar hâkim olduğunu ve bu kültürden nasıl beslendiğini gösterir. Dolayısıyla, bu çalışmada Sezen Aksu'nun yukarıda bahsi geçen iki şiir kitabından hareketle, eserlerindeki Türk kültür ve edebiyatının izleri araştıılmıştır. Çalışmada, özellikle şiir kitaplarından hareket edilmiş, Aksu'nun kitaplarına almadığı, başka bir isimle birlikte kaleme aldığı, fakat yine Türk kültür ve edebiyatından izler taşıyan bir şiirine de yer verilmiştir.

\section{AMAC VE YÖNTEM}

Çalışmanın amacı, Sezen Aksu'nun şair kimliğini ortaya koymanın yanı sıra, onun şiirlerindeki Türk edebiyatının izlerini sürmektir. Bunun için şairin yukarıda bahsi geçen iki kitabı dikkatli bir şekilde okunmuş ve Türk edebiyatına dair çeşitli çağrışımlar tespit edilerek not edilmiştir. Öncelikle şunu belirtmek gerekir ki Sezen Aksu'nun hemen her şiirinde Türk edebiyatından bir iz bulmak mümkündür. $\mathrm{Bu}$ yüzden, kitaplardaki şiirlerin büyük bir kısmı yaptığı çağrışımlar dolayısıyla araştırmanın konusu olmaya müsaittir. Ancak, biz bu çalışmamızda çok daha belirgin olan benzerlikleri, çağrışımları ve ihtimalleri söz konusu etmek istedik. Bu sebeple, Türk edebiyatından izler barındıran ve sayıca çok fazla olan şiirler arasında bir eleme yapılmışıı. Bunun yapılmasının nedenlerinden biri de tespitlerimizin "zorlama" olarak değerlendirileceğinden duyduğumuz kaygıdır. Dolayısıyla pek çok şiir, içinde az da olsa iz barındırmasına rağmen bu çalışmaya alınmamış ve söz konusu edilmemiştir.

Eldeki malzeme, Türk edebiyatındaki izler açısından incelenip yazılmak istendiğinde ise Sezen Aksu'nun farklı dönemlerden farklı şekillerde faydalandığı görülmüştür. Sezen Aksu, divan şiirinin tür ve şekillerinden yararlanmak yerine sadece mazmunlarından; yani kavramları dolaylı bir şekilde anlatmak için kullanılan sözlerden istifade etmiștir. Halk șiirine gelindiğinde ise bu sefer türkü ve ninni gibi türlere yakın eserler meydana getirmiştir. Cumhuriyet Dönemi ve sonrasındaki Türk edebiyatından esinlenme durumuna bakıldığında ise kimi zaman şair ve yazarlara doğrudan gönderme yaptığı kimi zaman da meşhur şiirlerdeki bazı kalıp ifadeleri kullandığı görülmektedir. Bazen ise yazdığı bir şiirin bir başka şairin üslubunu çağrıştırdığı anlaşılmaktadır. Dolayısıyla eldeki malzemeyi tutarlı bir şekilde ele almak ilk etapta çok güçtür. Ancak, çalışmayı bir metodolojiye oturtmak gerektiğinden farklı başlıklar içerse de şöyle bir yöntem ortaya çıkmıştır:

\section{A- DIVAN ŞIIIRINDEN İLER}

\section{1- Mazmun Bakımından Benzerlikler}

2- Konu Bakımından Benzerlikler

B- HALK ŞIIIRINDEN İZLER

\section{1- Tür Bakımından Benzerlikler}

2- Konu Bakımından Benzerlikler

\section{C- CUMHURIYYT DÖNEMİ VE SONRASINDAKİ TÜRK EDEBIYYATINDAN İZLER}

1- Başka Eserlere Göndermeler ve Kalıp İfadelerin Kullanımı

2- Üslup Bakımından Benzerlikler

3- Konu Bakımından Benzerlikler

\section{D- MÜSTAKIL BIR ŞEKILLDE ELE ALINMASI GEREKEN BİR Şİ̈R: RAKKAS}

"Divan Şiirinden İzler" kısmında önce eski Türk edebiyatında sıkça kullanılan mazmunların Sezen Aksu'nun şiirlerinde nasıl yer aldığına değinilmiştir. Değerlendirme yapılırken mazmun kullanımı bakımından klasik şiirlerle arasındaki farklardan da bahsedilmiştir. Sonrasında ise divan şiirinde sıklıkla ele alınan konuların Sezen Aksu'nun şiirindeki karşılığı söz konusu edilmiştir. "Halk Şiirinden İzler" 
kısmında önce türkü, ninni, ağıt gibi türlere yaklaşan şiirler ele alınmış ve halk şiirinden de örnekler verilerek karşılaştırmalı bir değerlendirmeye tabi tutulmuştur. Sonrasında halk şiirinde işlenen konuların, Sezen Aksu'nun eserlerindeki durumu ele alınmıştır. Üçüncü bölüm olan Cumhuriyet Dönemi ve sonrası ise daha farklı bir şekilde başlıklandırılmıştır. Önce şairin gönderme yaptığı Türk edebiyatının önemli eser ve sahipleri ele alınmıştır. Aynı başlık altında "Aldırma gönül”, "Sevgim acıyor.", "Dağlarına bahar gelmiş memleketimin" gibi şairleriyle özdeşleşmiş kalıp ifadelerin Sezen Aksu'nun şiirlerinde nasıl kullanıldığına değinilmiştir. "Üslup Bakımından Benzerlikler” kısmında ise Sezen Aksu'nun Ahmet Haşim'in üslubunu hatırlatan iki şiirine yer verilmiştir. Cumhuriyet Dönemi ve sonrasındaki Türk edebiyatında sıklıkla işlenen konuların Sezen Aksu'da nasıl yer aldığı da söz konusu edilmiştir. Son olarak ise divan, halk ve modern şiirin izlerinin bir arada olduğu ve Sezen Aksu'nun Yelda Karataş ile birlikte kaleme aldığı Rakkas'tan bahsedilmiştir.

\section{A- DIVAN ŞİiRINDEN İZLR}

\section{1- Mazmun Bakımından Benzerlikler}

1991 yılına ait Güllerim Soldu şiirinin ilk dörtlüğü dikkat çekicidir:

"Güllerim soldu kaldırımlarda

Gonca yüklü dallarıma ayaz vurdu

Demlerim oldu son akşamlarda

Bir nefeslik duraklarda çiçek açtım" (Aksu, 2018, s. 103)

İlk iki mısrada gül ve goncanın bir arada kullanılması manidardır. Kaldırım gibi herkesin gelip geçtiği yerlerde solan güllerin yanı sıra, bir olumsuzluk göstergesi olarak henüz açılmamış gül tomurcuklarıyla yüklü; yani goncalarla yüklü dallara da ayaz vurmuştur. Bu durum, olması gerekenin tersidir; çünkü goncanın kuru soğuğa değil, saba rüzgârına; yani sabah yeline ihtiyacı vardır. Bu rüzgârın gonca üzerinde önemi çok büyüktür. Gonca, ancak saba rüzgârıyla açılıp kendini gösterebilir. Görüldüğü gibi, şiirin ilk iki mısrannda gül ve gonca gibi divan şiirinde çokça karşılaşılan mazmunlara yer verilse de bunların içinde bulundukları durumun olumsuz olduğu anlaşılır. Bu mazmunlar, eski edebiyatta da kullanılmaktadır. Ancak, Sezen Aksu'nun bunlara yüklediği anlam ile divan şiirinde yüklenen anlam, tam manasıyla aynı daireye denk düşmemektedir. Dolayısıyla, bu şiirde divan edebiyatı mazmunları kullanılmış olsa da eski edebiyattaki kalıplarla Sezen Aksu'nun bu sözlerinin tam olarak örtüşmediği söylenebilir.

Üçüncü mısra ise kendisinden öncekileri tamamlar niteliktedir. "Demlerim oldu son akşamlarda" mısraında "dem" kelimesi pek çok şeyi ifade eder: zaman, nefes, içki, söz, gözyaşı ve kan (Pala, 2003, s. 120). Ardından gelen misrada dem ile aynı anlama gelen "nefes" kelimesinin kullanılması ise dikkat çekicidir: "Bir nefeslik duraklarda çiçek açtım" Kısacası, şairin bahsini ettiği akşamlarda demleri olmuştur; fakat burada, "dem" kelimesini tüm anlamlarının mısraa uygun düştüğü görülmektedir. Şair, en sonunda çiçek açabilmiştir, tüm zorluklardan sonra bunu başarır, ancak bu sefer de yanlış yerde açmıştır çiçeklerini. Çiçeklerini açtığı yer "bir nefeslik" duraklardır; yani kısa bir süreliğinedir. Burada da nefes kelimesinin zaman anlamında kullanıldığı görülür.

Divan şiirindeki mazmunlar bakımından benzerlik gösteren bir diğer şiiri ise 1994 yılında yazdığı La'l'dir. Arapça bir kelime olan lal, parlak kırmızı renkte olan değerli bir taştır. Aksu, şiirinde bu kelimeyi divan şiirinde de olduğu gibi şarap manasında kullanmıştır. Şiirin ilk dörtlüğünde de zaten "üzüm bağları"ndan bahsedilerek şarap ve kırmızı renk vurgusu yapılır:

"Bir bulut olsam, yüklenip yağsam

Dökülsem damla damla toprağıma

Bir deli nehir, bir asi rüzgâr olup

Kavuşsam üzüm bağlarına" (Aksu, 2018, s. 24)

Şiirin ikinci dörtlüğünde, "Bir çiğ tanesi, bülbülün çilesi” mısra1 ile gül-bülbül ilişkisine gönderme yapılır. Jale veya şebnem olarak da adlandırılan çiy, şiirde "çiğ olarak yazılmıştır ve akşamın \ gecenin 
serinliğiyle bitkilerin üstünde toplanan küçük su damlalarına denir. Bülbül kelimesinden hareketle, bu mısrada çiyin gülün üstünde olduğundan bahsedilebilir; çünkü bülbül divan şiirinde âşı̆̆ın sembolüdür. $\mathrm{Bu}$ tasavvurun en önemli sebebi ise sevgilinin gül olarak hayal edilmesidir (Sefercioğlu, tarihsiz, s. 414).

Şiirin dördüncü dörtlügünde bu sefer "çoban yıldızı" ifadesi dikkati çeker. "Komşunun kazı, çoban yıldızı" mısraiyla başlayan dörtlükte geçmişte kalan bir yaz mevsiminden bahsedilir. Divan şiirinde Zühre ismiyle karşımıza çıkan Çoban Yıldızı, Merkür'den sonra güneşe en yakın gezegendir. Eski Türk edebiyatında Zühre, genellikle bir eğlence meclisi içerisinde tasavvur edilir ve çalgıcı veya rakkase olarak düşünülür (Sefercioğlu, tarihsiz, s. 367). Aksu'nun şiirinin son dörtlüğünde de geçmişte bir yaz mevsimindeki eğlence meclisinden bahsedilmiştir. Çoban Yıldızı olarak tasavvur edilen komşunun kızı, bu meclisin çalgıcı ya da rakkasesidir:

"Komşunun kızı, çoban yıldızı

Yaz bahçeleri yeşil, mor, kırmızı

Ah şişede la'l, hem de ay hilal

Bir daha da görmedim öyle yazı" (Aksu, 2018, s. 24)

Bu dörtlükteki lal tam olarak şarabı temsil etmektedir. Divan şiirinde de lalin kimi zaman şarabı temsil ettiği bilinmektedir. Lal, kırmızı rengiyle de şarapla uyum gösterir. Şişede lal vardır, ay ise hilal şeklindedir. Bu durum "hem de ay hilal" ifadesiyle; yani sevinçle karşılanmışıtır. Hilal, divan şiirinde sevinçle ilişkilendirildiği gibi, kadehle de ilişkilendirilir. Hilal, aynı zamanda kırılmış bir kadehe benzer (Sefercioğlu, tarihsiz, s. 382). Kadehte ise şarap olur. Böylelikle lal ve hilal tasavvuru tamamlanmış olur.

Sezen Aksu'nun 2000 yılında yazdığı Kahpe Kader de divan şiirinden mazmunlar taşımaktadır. Türkçede, genellikle "kahpe felek" olarak kötü talih ve kader anlamında kullanılan ifade burada karşımıza daha farklı bir şekilde "kahpe kader" olarak çıkar. Buna rağmen, şiirin ilk iki mısraında felekten bahsedilmiştir:

"A benim avanak, arızall, arsız gönlüm

\section{Feleğin çemberine takılıp döndün ya" (Aksu, 2018, s. 35)}

Gök, gökyüzü veya sema olarak da bildiğimiz felek, divan şiirinde çokça karşımıza çıkar. Feleğin çemberine takılıp dönmek, aslında elde olmayan bir şeydir. Dünyayı dokuz felek çevreler. Dokuzuncu felek, cisimden arınmış olan ve bütün felekleri saran en büyük felek atlas feleğidir:

"Atlas feleği dönerken diğerlerini de kendi istikametinde dönmeye zorlar. Bu dönüş büyük bir özellik taşır. Kendi istikameti dışında dönüşe zorlanan sekiz felek, insanların talihleri, refah ve mutlulukları üzerinde değişken ve aksi durumlar ortaya koyar. İşte felekler üzerine şikâyet etmenin nedeni budur." (Pala, 2003, s. 159)

Aksu, şiirinde gönlüne seslenerek onun feleğin çemberine takılıp döndüğünü, yani kadere itiraz edemediğini, elinden bir şey gelmediğini dile getirmiş olur. Bu yüzden de gönlüne seslenirken onu çeşitli sıfatlarla anar: avanak, arızalı, arsız. Divan şiirinde gönül vasıflandırılırken genellikle şu sıfatlar kullanılmıştır: deli, divane, mecnun, şeyda, aşüfte, hevayi (Sefercioğlu, tarihsiz, s. 272). Bu şiirde ise Aksu, gelenekten farklı olarak aptal ve bön anlamındaki avană̆1; yılışık ve yüzsüz anlamındaki arsızı; son olarak da arızalı kelimesini tercih etmiştir. Kısacası, geleneği gönlü olumsuz sıfatlarla vasıflandırarak devam ettirmiştir.

Sezen Aksu'nun divan şiiri mazmunları açısından dikkati çeken bir başka şiiri ise İstanbul İstanbul Olalı'dır. 2002 yılına ait şiirin ilk kısmı şu şekildedir:

"Uzanıp Kanlıca'nın orta yerinde bir taşa

Gözümün yaşını yüzdürürüm hisara doğru

Yapacak hiçbir şey yok, gitmek istedi gitti

Hem anliyorum, hem çok acl

Tek taraflı bitti”' (Aksu, 2018, s. 149) 
Şairin şiirinde İstanbul'un bir semti olan Kanlıca'dan bahsetmesi şaşırtıcı değildir; çünkü Sezen Aksu'nun Kanlıca'da bir yalıda ikamet ettiği bilinmektedir. Karşı tarafta ise Rumeli Hisarı vardır. Bir taşa uzanmıştır ve gözyaşını Hisar'a doğru yüzdürür. Burada taş, gözyaşı, yüzdürmek ve hisar kelimeleri özenle seçilmiş ve boşuna kullanılmamıştır. Şair, her şeyden evvel ağlamaktadır. Ancak bunu doğrudan söylemek yerine sanatlı bir söyleyişi tercih etmiş teşbih ve istiareden faydalanmıştır. Kısacası, gözyaşını taşa benzetmiştir. Denizde taş sektirircesine, gözyaşlarını da taş misali denizin üstünde yüzdürür; yani sektirir. Taşın veya gözyaşının yönü ise Rumeli Hisarı'dır. Burada, eski edebiyattaki gözyaşı- taş ilişkisinden biraz daha farklı bir durum vardır. Divan şiirinde, eğer gözyaşı bir taşa benzetilecekse bu, değerli bir taş olur. Burada ise şair, gözyaşını herhangi bir taşa benzetmekle kalmamış, onu aynı zamanda deniz üstünde sektirmiştir.

Şiirin ikinci kısmı ise şu şekildedir:

"Bir lodos lazım şimdi bana, bir kürek, bir kayık

Zulada birkaç şişe yakut, yer gök kırmızı

Söverim gelmişine geçmişine ayıpsa ayıp

Düşer üstüme akşamdan kalma sabah yıldızı" (Aksu, 2018, s.149)

Kaçak ve yasak şeylerin saklandığı gizli yere zula denir. Şairin zulasında ise birkaç şişe yakut; yani şarap vardır. Şarabın rengi yakuta benzer; çünkü yakutun kırmızı, sarı ve gök renginde olanları varsa da en kıymetlisi kırmızı olandır (Pala, 2003, s. 492). Dolayısıyla, burada bir istiare yapılmış ve şarap yerine yakut kelimesi kullanılmıştır. Ardından gelen "yer gök kırmızı" ifadesi ise hem şarabın ve yakutun kırmızılığına hem de fecir; yani tan kızıllığına yapılan bir göndermedir. Şair sabahlamış ve sarhoş olmuştur, öyle ki sabah yıldızı diye tabir ettiği Çoban Yıldızı üstüne düşer. Çoban Yıldızı, diğer adıyla Zühre yahut Venüs, Güneş'e en yakın gezegendir. Aslında, bir yıldız değildir. Özellikle tan ağarırken gözle görülebilen bu gezegen, şiirde akşamdan kalma olarak nitelendirilir. Kısacası, geceki sarhoşluğunun mahmurluğunu taşır. Sarhoşluğun sebep olduğu sersemlik içindedir ve sabah olmaktadır.

\section{2- Konu Bakımından Benzerlikler}

1991 y1lına ait Zehir Gibisin şiirinin özellikle son dörtlüğünde, divan şiirinde çokça konu edilen "sevgiliden şikâyet" söz konusudur:

"Kederli şarkilar söyler gibi yüzün

Aldatır bu masum, bu yalancı hüzün

Dudakların acl, gözlerinde oklar

Kurşun gibi ă̆ır her sözün" (Aksu, 2016, s.21)

Divan şiirinde dudağın en belirgin özelliklerinden biri şirin; yani tatlı olmasıdır. Buna rağmen dudak, acı sözler söylemekten de uzak değildir (Pala, 2003, s.297). Bu şiirde de dudakların acılığından kasıt, acı sözler sarf etmesidir. Dolayısıyla sevgilinin her sözü kurşun gibi ağırdır. Sevgilinin gözlerinde ise oklar vardır. Divan şiirinde, bu okların ucunda "peykân" adı verilen sivri demir bulunur. Bu oklar elbette ki kirpiklerdir ve onların yaralayıcı, öldürücü vasıfları vardır. Sevgilinin yan bakışları ile âşığın kalbi yaralanır.

Sezen Aksu'nun 1995 yılında yazdığı Yaradana Kurban isimli şiirin ilk dörtlüğünde, yine divan şiirinde de yer alan "sevgiliden şikâyet" konusu değişik bir şekilde karşımıza çıkar:

"Aman aman ne canlar yandı kucaklarinda

Yalancı bahçeler, dikenli dudaklarında

Gözlerin bir deli macera, vefasiz

Vuruldum kirpiğin sandı̆̆ım bıçaklarınla”" (Aksu, 2016, s. 13)

Burada dudakların güle benzetilmesi durumu divan şiirinde de karşılaşılan bir şeydir. Özellikle rengi itibarıyla güle benzeyen dudak dikenlidir. Bu dikenli dudaklarda ise yalancı gül bahçeleri yer alır; yani 
dudaklar hep yalan söyler. Şair, sevgilisinin gözlerine vurgundur, ancak bu gözler kirpik denen bıçakları da ihtiva ederler. Divan şiirinde genellikle kılıç, hançer ve ok olarak karşımıza çıkan kirpikler, Aksu'nun şiirinde "bıçak" olarak nitelendirilmiştir.

Aksu'nun 1996'da yazdığı Çekirdek Hatun şiirinde de divan şiirinin konularından biri olan "sevgiliyi övme" söz konusudur. İlk dörtlük şu şekildedir:

"Ah beli daracık, çekirdek hatun

Gel dudăğna güller ekeyim

Kiz bu ne bereket, bu ne bolluk

Gel, müebbetini çekeyim" (Aksu, 2018, s. 56)

Özellikle ilk iki mısradaki bel ve dudak ifadeleri ile dikkat çeken şiirde, divan şiirinde bir güzeli vasıflandırmak için kullanılan ince ve dar bele gönderme yapılmıştır:

"Divan edebiyatında bel daima kll kadar ince ve dardır. Bu özellikleri ă̆ız ile ortak olduğundan çok zaman birlikte kullanilırlar." (Pala, 2003, s. 74)

$\mathrm{Bu}$ şiirde ağız değil de ağzın üst ve alt kenarı olan dudak beraber kullanılmıştır. Dudak kelimesinin ardından gül çiçeğinden bahsedilmesi de boşuna değildir. Burada gül, hem dudağın kırmızılığını çağrıştırır hem de "güller ekeyim" denilerek âşığın, sevgilinin dudaklarından öpme isteği ön plana çıkarılır.

Şiirin son dörtlüğünde de divan şiirindeki gibi “sevgiliyi övme” devam etmektedir:

"Ah gecesi ăglll, gündüzü beter

Yapamam, yapamam ben sensiz

Kâkülü mızrak, gözü hançer

Yatamam, yatamam ben sensiz" (Aksu, 2018, s. 56)

Burada da kâkülün şekil itibarıyla bir savaş aleti olan mızrağa benzetilmesi ve gözü hançer olarak nitelendirilmesi dikkat çekicidir. Göz, divan şiirinde hançere benzetilmiştir; çünkü gözde gamze; yani yan bakış bulunur, bunun yanında kirpik de vardır. Bunlar, âşıkta yara açarlar (Pala, 2003, s.202). Bu yüzden, bir savaş aleti olarak hançer de mızrağın yanındaki yerini alır.

\section{B- HALK ŞIIIRINDEN İZLR}

\section{1- Tür Bakımından Benzerlikler}

Sezen Aksu'nun 1995 yılında yazdığı, "gelin türküsü" türüne yakın bir eseri ise Ben Annemi Ísterim'dir. Bir gelinin ağzından yazılmıştır ve bize "Yüksek Yüksek Tepelere Ev Kurmasınlar" türküsünü hatırlatır. Mümtaz Sarıçiçek'e göre bu şiir, Anadolu kadınının ezilmişliğini ifade eder (Sarıçiçek, 2004, s.36) Aksu'nun şiirindeki gelinin, kocasına seslendiğini ve ona hitap ettiğini anlıyoruz. Tam anlamıyla bir sitem ve yakarış şiiri olan eser, kocaya şikâyetten ibarettir. Şiirdeki gelin ise Karadenizlidir:

"Uy çalsın kemençeler de ben bir horon tepeyim

Çatlasin kaynimgiller, bari kurtlarım dökeyim

\section{Fındı̆̆g ben toplarım, kırması sana düşer}

Uy ellerin iyisi, geh geh gerinip şişer" (Aksu, 2018, s.129)

Şiirin devamında baba ocağının gözünde tüttüğünü belirttikten sonra gelin, bu sefer dünyaya sitem eder.

Son iki misra ise vurucudur: 
"Bir bezden bebem vardl, bohçamda hayallerim

Kızlı̆gım yarım kald, ben annemi isterim”

Şiir, dile getirilenler; yani içerik bakımından bahsi geçen türküyü hatırlatmaktadır. Bilindiği gibi türkünün başı şu şekildedir:

Yüksek yüksek tepelere ev kurmasinlar

Aşrı aşrı memlekete kiz vermesinler

Annesinin bir tanesini hor görmesinler

Uçan da kuşlara mâlum olsun

Ben annemi özledim

Hem annemi hem babamı

Ben köyümü özledim (Göde, 2010, s. 166-167)

Bu türküde de Aksu'nun şiirinde olduğu gibi, gelin ayrılıp uzağa gitmiştir. Bu yüzden üzgündür ve türkü bu üzüntünün bir yansımasıdır. Koca evine gittikten sonra ağır basan anne, baba ve köy özleminin dile getirildiği bir türküdür. Aksu'nun şiirindeki gelinin bu türküdeki gelinden bir başka farkı ise daha isyankâr bir eda ile duyguların dile getirilmesidir.

Sezen Aksu, 1996 yılında bu sefer bir halk şiiri türü olarak "ninni” örneği vermiştir. Bu ninni her ne kadar bebeği uyutmak için söylense de ninninin ikinci ve üçüncü kısımlarında annenin, bebeğine verdiği hayata dair öğütler vardır. Ninninin ilk dörtlüğü şu şekildedir:

"Uyu da büyü

Bebeğim bebeğim

Ben sana e e e

Ninniler söyleyeyim" (Aksu, 2016, s. 58)

Annenin bebeği için temennilerinin yer aldığı ninniler halk şiirimizde fazlasıyla vardır. En büyük temenni ise bebeğin uyuması ve bir an önce büyümesidir:

"Beşiğimin altı şişe,

İçinde yatar paşa,

Ninnilerle uyusun ninni,

Beşikten kalksın büyüsün ninni!' (Çelebioğlu, 1987, s. 225)

(Merzifon)

Sezen Aksu 1997 yılında Dü̆ğ̈̈n isimli, "gelin ağıtı \türküsü” benzeri bir şiir örneği daha verir. Bu sefer şiirin başkişisi gelin olmak üzere olan bir genç kızdır. Dügünü vardır ve şiir tamamen babasına bir sesleniş ve yakarma şeklindedir. Şiirde üç defa kızın ağzından "Baba kapıyı kapatma." temennisi dile getirilmiştir. Genç kız endişelidir. Bilmediği bir yere gitmekte, yeni bir hayata başlamaktadır. Korkusu ise dara düştügünde babasının ona yüz çevirmesidir; çünkü Türk kültüründe "Baba evinden ak gelinlikle çıkan genç kız, gelin olarak gittiği evden ancak ak kefenle çıkabilir." inancı yaygındır. Kısacası, gelin olarak evden ayrılan genç kıza en baştan baba ocağının kapısı kapatılır ve ne olursa olsun, ne yaşarsa yaşasın onun baba evine dönmemesi istenir. Şiirdeki gelin olacak genç kız, işte bu yüzden endişelidir. O, başına bir şey gelirse geri dönebilmek ister:

"Parada, pulda gözüm yok inan baba

Eloğlu klyar gülünün fidanına

Olur a dara düşerim, ihtimal

Baba kapıyı kapatma 
Olur a dara düşerim, ihtimal

Gülüne su ver, unutma" (Aksu, 2018, s.130)

Baba evinden ayrılmanın zorluğu karşısında babaya bir yakarış vardır. Buna benzer "gelin ağıtları" halk şiirinde de mevcuttur:

"Ana gızın çok muyudu,

Bir kız sana yük müyüdü,

Girılası emmilerim,

Heç oğlunuz yok muyudu?

Baba gadanı alayım,

Sakalına tel olayım,

Gapında köle olayım,

Verme beni gurbet ele" (Feyzioğlu, 2010, s. 79)

Halk şiirimizde bu şekilde söylenmiş pek çok baba ocağından ayrılan "genç kı \gelin ağıtları" mevcuttur. Sezen Aksu da bu türlere yaklaşan bir örnek vermiş olur.

Aksu, 2005 yılında bir ninni örneği daha vermiștir. Kınalı Kuzum isimli “ninni”yi diğerlerinden ayıran ise çocuğun artık büyümüş olmasıdır. Annenin o küçük bebeği artık koca bir adamdır. Öyle ki ayrı eve bile çıkmıştır. Ancak annenin aklı hâlâ oğlundadır. Bir türlü bu duruma alışamamıştır ve sol yanı ince ince sızlamaktadır. Anne, "Büyüdün de adam mı oldun?” diyerek şiirin içinde şu "ninni”yi söyler:

"A nenni nenni kınalı kuzum

Büyüdün de adam mı oldun

Yană̆ pembem, dudă̆ı kirazım

Gözü okyanusum, iyi ki doğdun!" (Aksu, 2018, s. 51)

Ninnilerde, annelerin bu şekilde çocuklarını yücelttikleri bilinmektedir. Buna benzer bir ninni ise şu şekildedir:

"Ninni derim beni yakar,

Dudağından ballar akar,

Yavrum büyür bana bakar,

Ninni yavrum ninni!'” (Çelebioğlu, 1987, s. 224)

(Bursa)

Sezen Aksu, 2008 yılında Be Vefasız adlı şiiriyle halk edebiyatından izler taşıyan bir eser örneği daha verir. Bu şiir, "gurbet türküsü" özellikleri taşır. Yârim İstanbul'u Mesken mi Tuttun? adıyla bilinen Anadolu gurbet türküsünü hatırlatır. Bunu şiirin ilk dörtlügünden anlamak mümkündür:

"Be vefasiz!

Gözlerinden düştüm mü söyle

Gördün güzelleri

Kaldın mi gurbet elde" (Aksu, 2018, s. 181)

Türkünün ilk beş mısraı ise şu şekildedir: 
"Yârim İstanbul'u mesken mi tuttun

Gördün güzelleri beni unuttun

Sllaya dönmeye yemin mi ettin

Gayrı dayanacak özüm kalmadı amman

Mektuba yazacak sözüm kalmadı amman" (Mirzaoğlu, 2019, s.854)

Sılada kalmış bir gelinin ağzından yazılan şiirde yine sitem ve serzeniş yer alır. Gelin, kocasını hasretle beklemektedir. Öyle ki içeceği çorbasını ocağa koymuş, kocasının gömleklerini de yıkayıp asmıştır. Geline göre artık gurbetten dönme vakti gelmiştir:

"Çorbayı koydum ocă̆a

Tuz basiyorum

Yıkadım gömleklerini

Tez aslyorum" (Aksu, 2018, s. 181)

Şiirde geçen gömlek motifi türküde de yer almaktadır:

"A Ăamın geydiği ketenden gömlek,

Yok imiş dünyada öksüze gülmek,

Gurbet ellerinde kimsesiz ölmek,

Gayrı dayanacak özüm kalmadı amman

Mektuba yazacak sözüm kalmadı amman.” (Mirzaoğlu, 2019, s. 854)

Aksu'nun şiirinin son dörtlüğü ise şu şekildedir:

"Al kuşak sardım belime

Has ipek serdim evime

Sevdiğim ak düşmeden dön, gel

Saçımın teline" (Aksu, 2019, s.181)

$\mathrm{Bu}$ dörtlükteki "kuşak" ve "sermek" kelimelerini ise türkünün bir başka çeşitlemesi olan Ăgam İstanbul'u Mesken mi Tuttun'da görürüz:

“Ăgamin döktürdü̈̆̈̈ burma kuşağ

Kime koyup gidiyon oğlan uşăgl

Gurbet ele kaba serdin döşeği

Neyleyim dünyada dünya malını

Gönül arzuluyor eski yârini”" (Mirzaoğlu, 2019, s.854)

Aksu'nun şiirindeki gelin, endişelidir. Yârinin bir an önce dönmesini arzular. Bu yüzden sevdiğinin, kendi saçının teline ak düşmeden dönmesini ister. Sanki sonunun bu türküdeki kadın gibi olmasından korkmaktadır. Yârim İstanbul'u Mesken mi Tuttun? türküsünün hikâyesinde bekleyen kadın ölmektedir:

"Günler aylarl, aylar yılları kovalar... Koskoca yedi yıl geçse de Ali gelmez. Gelin üzüntüsünden yataklara düşer, ince hastalı̆̆a yakalanır; yani verem olur, muradına eremeden göçüp gider bu dünyadan. Ardında, yaşadiğı bu umutsuz hayatın öyküsü ve türküsü kalır. Bu kırı, kederli öykünün nedeni ise İstanbul gurbetidir." (Mirzaoğlu, 2019, s. 855)

\section{2- Konu Bakımından Benzerlikler}

Ağıt, halk edebiyatında yer alan bir türkü çeşididir. Ağıtlar sadece ölen kişi ya da kişilerin arkasından söylenmez. Aynı zamanda, insanların canlı-cansız bir varlığı kaybetme, korku, telaş ve heyecan anındaki 
üzüntülerini, feryatlarını, isyanlarını, talihsizliklerini dile getirdikleri söz ve ezgilerle ifade edilen türkülere de denir (Elçin, 2000, s. 290). Sezen Aksu da halk edebiyatından faydalanan ve beslenen biri olarak bu tip ağıtlardan esinlenmiş olmalıdır. Aslında bilinen gelin ${ }^{4}$ veya genç kız ağıtlarından çokça farklılık gösterse de konu / içerik açısından yaklaşılırsa Onu Alma Beni Al 'in ilenmeli ağıt ya da türküye yaklaştığı söylenebilir. ${ }^{5} 1995$ yılında yazdığı Onu Alma Beni $\boldsymbol{A l}$ isimli bu şiir, ilenmeli bir gelin ağıtının içeriğine / konusuna benzer. Konu bakımından benzerlik taşımasına rağmen, özellikle bu şiirin müzikli hâlini göz önüne alırsak bu sefer de şiir "ağıt" tan uzaklaşmaktadır. Bilindiği gibi Sezen Aksu'nun bu parçası hareketli ve neşeli bir şarkıdır. "Ağıt"ların ezgileri, konusu dolayısıyla hareketli ve neşeli olmaz. Dolayısıyla, bu şiir konu / içerik bakımından "ağıtt"a yaklaşsa da bir bütün olarak ezgisiyle beraber düşünüldügünde "ilenme"yi daha çok andırmaktadır.

Yukarıda belirtildiği gibi, gelin ağıtlarında sadece ölüm yoktur. Bu ağıtlarda çeşitli olaylar ve sosyal olgular da etkilidir:

"Diğer gelin ağttlarında, çeşitli olaylar ve sosyal olgular etkilidir. Geleneksel evlilikler, bir felaket sonucu ölüm, iftiraya uğrayan gelin, çocukla evlendirilen gelin, uzaklara, gurbete giden gelinlerle ve diğer sebeplerle ilgili yakılan ağıtlar bu başlık altında değerlendirilebilir.” (Feyzioğlu, 2010, s. 79)

Gelin ağıtlarında görülen serzeniş, beddua ve yakarış Sezen Aksu'nun bu şiirinde de görülür. Şiir, aldatılmış ve kandırılmış bir genç kızın ağzından yazılmıştır. Genç kız yıllarca ümitle beklemiş, çeyizini hazırlamış, hayaller kurmuş; fakat sevdiği erkek onu terk edip bir başkasıyla evlenmiştir. Üstelik bu başkası kendisinden oldukça aşağıdadır. Bu durumu hazmedemeyen genç kızın türküsü bu yüzden sitem, serzeniş ve beddualarla örülüdür:

"Bak atının terkisine de atmış gözleri şaşı gelini

Mor kaftanlara sarmış haspam odun gibi belini

Ah verin elime de kirayım cadinin derisi kara elini

Seni gidi dilleri fitne fücur, klyametin gelsin" (Aksu, 2018, s. 49)

İlk dörtlükte kendisinin yerini alan gelini tasvir eden, ona hakaret edip aşağılayan kalbi kırık genç kız, yeni geline de beddua etmekten kendini alamaz. Hıncını bir türlü alamayan genç kız, şiirin ikinci bölümünde yeni geline seslenmeye devam eder:

"Sen o alacast içinde fesatla hangi gününü gün edicen"

Burada alacası ifadesiyle tam olarak söylenmek istenen "deli alacası"dır. Deli alacası, birbirini tutmayan parlak renklerden oluşan anlamındadır ve yeni gelinin üstündeki kıyafet tam anlamıyla böyledir. Ancak, genç kızın yerini alan gelin içinde fesat barındırmaktadır. Türküyü söyleyen genç kız yukarıdaki fitne fücur ifadesiyle yetinmemiş, bu sefer de fesat kelimesini kullanma gereği duymuştur.

Türküyü söyleyen genç kız, bu sefer damada yani eski yârine seslenir:

"Ah o kaditin üstüne bir de atlas yorgan sericen"

Kadit, çok zayıf olan kişiler için kullanılan bir sözdür. Genç kıza göre, sevdiği adamın kendisinin yerine aldığı gelin şaşı, odun gibi bele sahip ve cadı olmanın yanı sıra bir de çok zayıftır. Genç kıza göre, böyle bir insanın üstüne atlas yorgan; yani ipekli kumaştan yorgan yakışmaz. Bu yüzden bir de eski yârine beddua eder:

\section{"Amanın amanın yansın ocağın barkın"}

Genç kız, eski yârinin ağasının ve emmisinin utanmasını da diler; çünkü anlaşıldığı kadarıyla bu iş onların başının altından çıkmıştır. Onların da kendisinin düştüğü bu kötü duruma sevindiklerini bilmektedir. Bu sebeple de mecazen damadın ağa ve emmisinin her bir yerlerine kırmızı kınalar

\footnotetext{
4 “Türk topluluklarında oğlun karısına 'Gelin' denir. Etimolojisine göre, 'gelen kimse' demektir. Klz gelin olarak ata binerken klz evi ağlar ve yas tutar. Bunda klza olan şefkat ve ilginin hissesinin yanında kuracağ yeni hayatla ilgili, baba evinden uzak yeni bir hayat kurması belirleyicidir." (Feyzioğlu, 2010, s.78)

${ }_{5}^{5}$ Mümtaz Sarıçiçek, bu şiirin Anadolu kadını ağzıyla dile getirilen bir metin olduğunu ifade etmiştir. (Sarıçiçek, 2004, s.35)
} 
yakmasını söyleme gereği duyar. Hayıflanır, üzülür; çünkü aldatılmıştır. Emek emek çeyiz düzmüştür, hazırladığ 1 bu çeyize yanar ve yine beddua eder:

"Varsin bize vursun felek

Ne çeyiz düzdüm emek emek

Allah bildiği gibi yapsın" (Aksu, 2018, s. 49)

Ardındansa zalim ve hain olarak nitelendirilen sevgiliye yalvarır:

"Bana ne bana ne, beni al

Onu alma!"

Genç kız, ilenmeli türküsünü yine bir sitemle sonlandırır. Genç kızın kiraz gibi dudakları al al dururken ve tek başına kara gecelerde zar zor uyurken yârin bu davranışı hiç reva değildir. Etrafını ise çakal ve kurt gibi tehlikeli hayvanlara benzeyen insanlar sarmıştır. Genç kızın bu hâli, eğer yârin içine siniyorsa işte o zaman söyleyecek tek söz vardır: "Kuyametin gelsin!"

2008'de anonim bir halk türküsünden izler taşıdığını düşündüğümüz bir şiir daha kaleme alır. Adı Deli Ŏğlan olan şiirde genç bir kızın sevdiği erkeğe yaptığı bir çağnı vardır. Genç kız bir taraftan aşkını ilan ederken diğer taraftan da erkeği bu aşka davet eder:

"Hadi deli oğlan, hadi belime dolan

Hele bi öp bakalım kızı dudağından”(Aksu, 2016, s. 126)

Buna benzer ve aynı konuyu işleyen anonim bir türkü vardır. Türküde sürekli şu dörtlük tekrar edilir:

"Hadi güzel oğlan oğlan

Yaniyorum eylen eylen

Evli isen aş git oğlan

Bekârısen eylen eylen" ( Gözaydın, 1989, s. 104)

Bu türküde de aynı şekilde genç bir kızın yaptığı çağrıyı görürüz. Kız, aynı şekilde aşkını itiraf eder ve "yanıyorum" der. Ancak, karşısındakinin evli mi yoksa bekâr mı olduğunu bilemez. Bunun için de evli ise gitmesini; fakat bekâr ise kalmasını söyler.

\section{C- CUMHURIYET DÖNEMİ VE SONRASINDAKİ TÜRK EDEBIYYATINDAN İZLER}

\section{1- Başka Eserlere Göndermeler ve Kalıp İfadelerin Kullanımı}

Sezen Aksu, 1988 yılında yazdığı Unut isimli şiirindeki bir dizeyi Eksik Şiir İkinci Kitap'ta yıldızla işaretleyerek sayfanın altına bir dipnot düşmüştür. Dipnotta, şiirdeki "Unut her yalan gibi" dizesinin, Ümit Yaşar Oğuzcan'ın "Yabancı" isimli şiirine gönderme olduğu belirtilir:

"O sevgiler ki yoktular

\section{Onlar ümitlerimizdi}

Ne ümitler yaşandı gel zaman git zaman

Ayrildığımızı unut

Yalnizliklar zaten yalan

Unut, beni de her yalan gibi unut" (Aksu, 2016, s.72)

Aksu'nun 1992'de yazdığı Aldırma Deli Gönlüm şiirinde, Sabahattin Ali'nin Hapishane Şarkısı V isimli eserindeki “Aldırma gönül” kalıp ifadesini bulmak mümkündür. Bilindiği gibi, Sabahattin Ali’nin bu şiirinin ilk dörtlügü şu şekildedir: 
“Başın öne ĕgilmesin,

Aldırma gönül, aldırma;

Ağladığıı duyulmasın,

Aldırma gönül, aldırma ..."

Sezen Aksu ise

"Aldırma deli gönlüm, giden gitsin

Sen şarkılar söyle içinden, boş ver!'” ( Aksu, 2018, s. 107) der.

Bu çalışmada nasıl Sezen Aksu'nun bahsi geçen şiirinin, Sabahattin Ali'nin Hapishane Şarkısı V isimli eserini hatırlattığı düşünülüyorsa Cafer Gariper de Hapishane Şarkısı V'e Karacaoğlan'ın, her dörtlüğü "Gamlanma gönül, gamlanma” diye biten şiirinin kaynaklık ettiğini düşünmektedir:

"Sabahattin Ali'nin Karacaoğlan'ın şiirini yaşadığı devrin şartları içerisinde kendi psikolojik dünyasıyla yoğurarak yeni bir mahiyet kazandırmış olduğunu, yani edebi eser seviyesinde dönüştürdüğünü söyleyebiliriz. Kendisine örneklik teşkil eden Karacaoğlan'ın şiiriyle kurduğu paralelliklere ve benzerliklere rağmen şiirine farklı bir mahiyet kazandırdığını görmekteyiz." (Gariper, 2002, s. 70)

Sezen Aksu'nun bu şiiri, gönle aldırmamasını söylemesi açısından Hapishane Şarkısı V'i andırsa da tevekkül ve razı oluş açısından, Karacaoğlan’ın bahsi geçen şiirine de yakın durmaktadır. Şiirlerdeki ilk iki dörtlüğü karşılaştırmak bile, bu tevekkülü ve razı oluşu ortaya çıkarır:

Her gün bir şey daha biter

Giderek acı vermez biten şeyler

Kayıtsız bir razı oluş başlar

Sıradan izler bırakır en tutkulu aşklar (Aksu, 2018, s. 107)

Karacaoğlan'1n türküsünün ilk dörtlüğü ise şu şekildedir:

Koyun meler kuzu meler

Sular hendeğine dolar

Ağlayanlar bir gün güler

Gamlanma gönül, gamlanma (Gariper, 2002, s.70)

Cafer Gariper, Sabahattin Ali'nin şiirinde kabullenilmiş hâlin içinde gizli bir başkaldırı olduğunu belirtir. Sezen Aksu'nun şiirinde ise daha çok bir razı oluş ve aldırmama söz konusudur. Bu yüzden kendisine şu düşünceyi telkin eder: Giden gitsin, sen şarkılar söyle içinden, boş ver!

Sezen Aksu'nun 1994 yılında yazdığı Sevdam Ă̆llyor isimli şiir, Aksu tarafından “Turgut Uyar'a saygıyla..." notuyla yayımlanmıştır. Aksu'nun şiirinin özellikle son dörtlüğü okunduğunda neden şiirin başında Turgut Uyar'ın anıldı̆̆ı anlaşılır:

"Ne sarayda ne handa

Bir zalim ocă̆ında sevdam ă̆lıyor

Ne gam ölsem uğrunda

Beni zehir zemberek diller dăglıyor" (Aksu, 2016, s. 196)

$\mathrm{Bu}$ şiirdeki “sevdam ağlıyor" sözü, bize doğrudan Turgut Uyar'ın Acıyor şiirindeki "sevgim acıyor” kalıp ifadesini hatırlatır. Turgut Uyar'ın şiirinde görülen hayatın dengesizliği konusu, Aksu'nun şiirinde de işlenmiştir. Karşı taraf gönül alır; fakat bir duru sözle. Çiçekle gelir; fakat bir kuru dalla. Turgut Uyar' ın şiirinde görülen mutsuzluk gerçeği, Aksu'nun şiirinde de vardır. Ancak Uyar, mutsuzluktan söz etmek istemez: 
"Şair için denge, hayatın en temel sorunlarından biridir. Bununla birlikte iyilik ve kötülük güçleri, mutluluk ve mutsuzluk, umut ve umutsuzluk, var oluşun dayanılmaz acısını yaşarken tek başına kalmak, varlık ve yokluk, boşluklar arasında denge kurmak, imkânsızı arzulamaya benzer.

Mutsuzluktan söz etmek istemiyorum

Dikey ve yatay mutsuzluktan

Mükemmel mutsuzluğundan insan soyunun

Sevgim acıyor" (Özger, 2011, s. 138)

Aksu'nun şiirinde de aynı mutsuzluğu görürüz. Sevdası bir zalimin ocağında ağlamaktadır. Sevdiğinin uğrunda can verse bile üzülmeye gerek yoktur; çünkü onu zaten zehir zemberek, son derece sert, hakaret dolu diller dağlamaktadır. Kısacası, acısı yüreğine işlemektedir.

Sezen Aksu, 2008 yılında Rahatı Kaçan A da aynı isimli bir şiiri vardır. Aksu, kitabında dipnot şeklinde bir açıklama yazarak bu şiirin, Anday'ın eserine gönderme olduğunu belirtir ve Melih Cevdet'in şiirini verir:

"Tanıdı̆̆ım bir ăgaç var

Etlik bağlarına yakın

Saadetin adını bile duymamış

Tanrının işine bakın

Geceyi gündüzü biliyor

Dört mevsimi, rüzgârl, karı

Ay ışı̆̆ı̆na bayılıyor

Ama kötülemiyor karanlı̆̆

\section{Ona bir kitap vereceğim}

Rahatını kaçırmak için

Bir ögrrenegörsün aşkl

Ă̆acı o vakit seyredin.”

Aksu, şiirinin tamamında hayatının ne kadar perişan ve tekinsiz olduğundan dem vurur. Hayatı, hayalle hakikat arasındaki ince çizgide geçmiştir. Aklı ise sürekli gidip gelmededir. Aklı kendisine bir türlü söz geçiremediği gibi, o da aklına söz geçirememiştir. "Ahlaksız yüreği”nin frenleri ise hiç tutmamış, hep yüreği galip gelmiştir.

"Ah çok acl, ah çok acl

Hatırladım 'Rahatı Kaçan Ağaç'ı

Resmidir daha da yalnızlaştığımın..." (Aksu, 2016, s. 98)

Kısacası şair, hayatında aşk denen şeyi tatmıştır. Bu yüzden, tamamlanmamış hikâyeler gibidir ve hatırlamaktan perişan bir vaziyette, ancak sabahları uykulara dalabilmektedir. Aşk, birlikte ayrılığı ve 1zdırabı da getirmiştir. Aşk acısı çekmektedir ve mutlu değildir. İşte bu psikolojideyken "Rahatı Kaçan Ağaç" şiirini hatırlar şair ve daha da yalnızlaştı̆̆ını anlar. Aslında, kendisi de tıpkı o şiirdeki ağaç gibidir. Aşkı tanımış ve rahatı kaçmıştır. Ancak, şairin Anday'ın şiirini hatırlamasıyla beraber yalnızlaştığını da anlaması ilginçtir. Demek ki şair, gerçekten büyük bir aşk acısı çekmektedir. Sevdiğiyle beraber, mutlu ve âşık olan birinin böyle bir zamanda bu şiiri hatırlaması anlamsızdır. Anday'ın şiirinin hatırlanabilmesi için, şairin yalnız ve mutsuz olması gerekir. Kısacası, kendisinin de rahatı kaçan bir ağaç olduğunu fark 
edebilmesi için aşk ızdırabı gerekir. Demek ki aşk, aslında rahatsızlık veren bir hastalıktan başka bir şey değildir.

Sezen Aksu'nun 2008 yılında yazdığ bir başka şiir ise Kutlama'dır. Bu şiirin özellikle ilk dörtlüğü okunduğunda Ahmet Arif' in "Dağlarına bahar gelmiş memleketimin..." diye biten şiiri hatırlanır:

"Memleketime çoktan bahar gelmiştir

Başaklart şimdiden göğe ermiştir

Dağlarını gelincik basmıştır

Yer, gök ve yürek çiçek açmıştır" (Aksu, 2016, s.179)

$\mathrm{Bu}$ şiirde, şair baharın geldiğinden çok da emin değildir. Memleketinden uzaktadır; fakat mevsim ve zaman itibarıyla baharın gelmiş olabileceğini tahmin etmektedir. Böyle bir zamanda başakların göğe erdiğini düşünür. Dağları gelincik basmış olmalıdır. Yürek dâhil her yer çiçek açmış olmalıdır. Ahmet Arif de memleketinden uzakta ve hapistedir. Memleket hasreti içini yakar kavurur:

"Cemal Süreya, Nazım Hikmet'i şehirli, ovalardan ve düzlüklerden insanlara seslenen bir şair olarak tanımlar. Ahmet Arif'in ise dağll "asi” bir şair ve şiirlerinin de oral (ă̆za ilişskin) şiirler olduğunu söyler. Güneydoğu insanının yaşamından kesitlerin açıkça görülddüğü şiirlerinde Anadolu'yu ve insanını ölesiye sevmeye şahit oluruz. Halk türkü ve deyişlerinden yararlanarak bu sevgiyi ortaya koyar. Tutukluluk günlerinin gerçeğine vurgu yaparken söylediği benim orada bad-ı saba bile olamazdl. Çünkü kapalı bir yer, zincirli... Adı üstünde hücre... Ancak bir somya slğıyor. Onun da önünde otuz santimetre bir boşluk ya var, ya yok.' ifadelerinin Anadolu insanının bir özleyiş olarak şiirine girdiği şeklinde yoruma imkân vermektedir. Tutsaklıkta bile şairi memleket hasretini terennüm etmekten alıkoyamaz. Yalnızlı̆̆ını intak sanatı ile gidermeye çalışır. Süreya'ya göre şairin kullandı̆̆ı imgeler sıradandır ancak çok canlı ve günceldir. Hapis yaşamını memleket sevgisi ile ilintiler." (Uludağ, 2013, s.205)

Görüşmeci, kendisine yeşil soğan getirmiştir. Sigarası ise karanfil kokmaktadır. Hapishanedeki şair, bunlardan hareketle memleketine bahar geldiğini anlar:

"Haberin var mı taş duvar?

Demir kapl, kör pencere,

Yastığım, ranzam, zincirim,

Uğruna ölümlere gidip geldiğim,

Zulamdaki mahzun resim,

Haberin var mi?

Görüşmecim, yeşil soğan göndermiş,

Karanfil kokuyor cigaram,

Dağlarına bahar gelmiş memleketimin...” (Uludağ, 2013, s. 205-206)

Aksu, 2009 yllında Yasak Elmam adlı bir şiir yazar. Bu şiirin son dörtlügünde, Attilâ İlhan'ın Mahûr'una gönderme vardır. Attilâ İlhan'ın bu şiirinde adı geçen Müjgân için şunlar söylenebilir:

“Attila İlhan'ın kadın karakterlerinden biri olan Müjgân, Balkan Savaşı izlenimlerini o dönemin atmosferinde yaşanan bir sevda dramıyla Türk sanat musikisi makamlarının iç içe geçtiği eski rumeli bölümündeki şiirlerde ortaya çıkmıştır. Çolpan İlhan'ın eşi Sadri Alışık'ın kendi sanatına ve esprisine uygun olarak yarattığı Müjgân tipinin de çıkı̧s noktası bu karakter olabilir.” (Ecevit, 2018, s.112)

Kısacası Müjgân, İlhan'ın şiirlerinde zaman zaman ortaya çıkan bir sevgilidir:

"Attilâ İlhan'ın şiirlerinde öne çıkan tiplerden biri olan Müjgân, bazı şiirlerinde onun dert ortağl, bazılarında ise sevgilisidir."'(Ecevit, 2018, s.190) 
Attilâ İlhan'ın şiirinin ilk bölümü ise şu şekildedir:

"şenlik dağıldı bir acı yel kaldı bahçede yalnız

o mahûr beste çalar müjgân'la ben ağlaşırı

gitti dostlar şölen bitti ne eski heyecan ne hiz

yalnız kederli yalnızlı̆̆ımızda sıralı sırasız

o mahûr beste çalar müjgân'la ben ağlaşırız" (Ecevit, 2018, s. 267)

Sezen Aksu da kendi şiirinde, bu esere bir gönderme yaparak şöyle der:

"Yunuslar geçti bugün balıkçılarla boğazdan

Yatsida, Karadeniz'de dinlenirler birazdan

Karşı sahilden rüzgâr o mahur besteyi esti

Ağllyoruz Attila İlhan, ben ve Müjgân" (Aksu, 2016, s.96)

Aksu 2010 yılında ise Esmer isimli bir şiir yazar. Bu şiir, bir erkeğin ağzından yazılmıştır ve Bedri Rahmi Eyüboğlu'nun Karadut şiirini çağrıştırır. Karadut şiirini Eyüboğlu sanıldığı gibi karısı için değil, sevgilisi için yazmıştır:

"Sevilen biri için yazıldı̆̆ı çok açık olan bu şiir şairin sevgisinin büyüklüğ̈̈nü ortaya koymaktadır. Mehmet Kaplan Şiir Tahlillerinin ikinci kitabinda 'Karadut' adl şiiri değerlendirmesine 'Karadut șiirinde Bedri Rahmi Eyuboğlu karısına karșı olan sevgisini ifade ediyor.' cümlesiyle bașllyor. Oysa bu şiir Bedri Rahmi'nin karısı için değil, evliyken sevdiği bir Ermeni kızı için yazılmuştır. Bedri Rahmi'yle akademide heykel ögrrencisi olan Mari Gerekmezyan'ın aşkı bilinmiyor olsaydı şiirdeki verilere göre elbette Bedri Rahmi'nin karısına duyduğu sevginin şiiri olduğuna herkes katılacaktı. Çünkü Bedri Rahmi ve karısı Ernestino Letoni'nin de büyük bir aşk öyküleri vardı. 1932'de Paris 'te başlayan ülkelerine dönmelerinden sonra birkaç yll mektuplarla süren bu aşk Bedri Rahmi'nin ailesinin gönülsüz kabulüyle 1936'da evliliğe ulaşmıştır. Karısına karşı böyle büyük bir aşk besleyen Bedri Rahmi daha sonra Mari'ye de âşık olmuştur. Bu aşktan, evlendikten sonra adı Ernestino'dan Eren'e dönüşen karısının haberi vardır. Kendisi de bu aşkı gizlememiştir." (Aydoğan, 2005, s.92)

Eyüboğlu'nun şiirinin ilk kısmı şu şekildedir:

"Karadutum, çatal karam, çingenem

Nar tanem, nur tanem, bir tanem

A ̆gaç isem dalımsin salkım saçak

Petek isem balımsin ăgulum

Günahımsın, vebâlimsin" (Aydoğan, 2005, s.91)

Aksu'nun şiirinde de birinci teklik şahıs iyelik ekini kullanılarak sevgiliye seslenilir. Eyüboğlu, sevdiğine meyveler aracılıyla seslenirken Aksu, "yaralı ceylanım, kırılgan dalım, boyun eğmezim, yabanım, isyankârım" diyerek seslenmeyi tercih eder:

"Yaralı ceylanım, kırılgan dalım

Boyun eğmezim, yabanım, isyankârım

Nefesin kesik kesik nefesimde

Bir kızll gonca islak dudakları"” (Aksu, 2016, s. 119)

Eyüboğlu, "ağaç isem dalımsın salkım saçak" diyerek sevdiğini bir dala benzetirken Aksu'nun şiirinde de "kırılgan dalım" ifadesinde bu benzetmeyi buluruz. Eyüboğlu'nun şiiri şöyle devam eder: 
"Dili mercan, dizi mercan, dişi mercan

Yoluna bir can koyduğum

Gökte ararken yerde bulduğum

Karadutum, çatal karam, çingenem

Daha nem olacaktın bir tanem

Gülen ayvam, ağlayan narımsin

Kadınım, kısrağım, karımsın." (Aydoğan, 2005, s. 91-92)

Eyüboğlu karadut, çatalkara (üzüm), ayva ve nar gibi meyveleri ön plana çıkartarak sevdiğine sesleniyor. Aksu'nun şiirinde ise meyve olarak sadece kayısının adı geçer ve bu meyve sevgilinin teniyle ilişkilendirilir:

"Kaylsı tadı fişkiran teninde

Tutuşur ellerim sedef teninde

Uyandım koynunda ilk gençliğime

Ele geçmezim, kekliğim, kısrağım" (Aksu, 2016, s.119)

Eyüboğlu şiirini "kadınım, kısrağım, karımsın" diye bitirirken Aksu "ele geçmezim, kekliğim, kısrağım" diye bitirmeyi tercih eder. Eyüboğlu'nun şiirinde bahsini ettiği meyvelerden hareketle, şiirde daha çok kırmızı rengin hâkim olduğu söylenebilir:

'Şiirde 'kırmızı' renkteki unsurların Türk ve Çin mitolojisinde uzun ömürlülüğ̈̈n, mutluluğun, neslin devamlılığınin ve şehvetin simgesi olan 'kısrak' (genç dişi at) kelimesiyle birlikte kullanilması tesadüf değildir. Her iki unsur da aşkı ve hazzı ifade eder." (Koşar, 2010, s. 85)

Sezen Aksu'nun bu şiiri bir erkeğin ağzından yazdığını yukarıda ifade etmiştik. Şair, tıpkı Eyüboğlu gibi sevdiğine "kısrağım" diye seslenir; fakat yanında bir hitap daha vardır: "kekliğim". Bilindiği gibi keklik, tüyü boz, ayakları ve gagası kırmızı renkte bir kuştur. Güvercin büyüklügündedir ve eti için avlanır. Keklik, mecazi anlamda ise alımlı ve güzel kadına denir. ${ }^{6}$

Sezen Aksu, 2014 yılında yazdığ Guguk isimli şiirinin son dörtlüğü şu şekildedir:

"Nerede hukuk yok, orada guguk

Tanrı aşkına insaf eyle

Boşuna mı söylemiş bize Yaşar abi

Al gözüm Salih, seyreyle" (Aksu, 2016, s.41)

"Guguk" tek başına kalmak veya oturmak anlamlarında kullanılan, "guguk gibi kalmak" veya "guguk gibi oturmak" deyimlerinde geçen bir sözdür. ${ }^{7}$ Hukukun olmadığ yerde, insanın tek başına kalacağının ifade edildiği şiirde, Yaşar Kemal'in Al Gözüm Seyreyle Salih adlı romanına gönderme yapılmış ve bu göndermenin yapıldığı, üçüncü mısraın sonuna bir dipnot konmak suretiyle, sayfanın altında Sezen Aksu tarafından açıklanmıştır. Dolayısıyla, şair okuyucuya yardımcı olmak için nereden beslendiğini apaçık söylemiştir. Burada, bahsi geçen ve 1976'da yayımlanan romanda, on bir yaşında bir çocuk olan Salih isimli kişinin gözünden dönemin siyasi, sosyolojik ve hukuki yapısının anlatıldığını da belirtelim.

\section{2- Üslup Bakımından Benzerlikler}

İlk şiir kitabı olan Göl Saatleri'ni 1921 yılında, ikinci şiir kitabı Piyale'yi 1926'da yayımlayan Ahmet Haşim, Cumhuriyet Dönemi öncesinde de sonrasında da eser vermiş bir şairdir. Sezen Aksu'nun bazı şiirleriyle Ahmet Haşim'in üslubu benzerlik göstermektedir. Bunlardan biri Rastgele'dir. 1995 yılında yazılan Rastgele' de çiçek olarak gül, ön plana çıkmaktadır:

\footnotetext{
${ }^{6}$ https://sozluk.gov.tr/

7 https://sozluk.gov.tr/
} 
“Bir gül bıraktım gün batımında suya

Gül sere serpe uzandı kuytuya

Yüreğim güvercin, vakit alacakara

Rastgele deli gönül hattralara" (Aksu, 2018, s.177)

Güneşin ufukta kaybolması; yani gurup zamanı suya bir gül bırakılmıştır. Gülün genellikle kırmızı olduğu düşünülürse onunla gün batımı arasındaki renk uyumu ortaya çıkar. Gül, rüzgâr almayan tenha bir yere sere serpe uzanır. Şairin yüreği güvercindir; yani pır pır etmektedir. Tıpkı kuş kanadının çıkardığı ses gibi, ancak heyecanlıdır da. Vakitse alaca karanlık; yani akşam karanlığıdır. Gülü suya atan şair ardından, gönlüne "İşin rast gitsin." anlamında "Rast gele!" der. Gönül, bir balık avcısıdır ve hatıralar denizine dalmıştır. Şaire düşense bu denizde avlanmaya çalışan deli gönlüne "Rast gele!" demektir. İkinci dörtlük şu şekildedir:

"Feryat feryat geçiyor içimden yıllar

Íki gözüm iki kara bulut, ağlar

Tenhalarda demleniyor dilsiz

Kırık dökük sevdalar sırlar" (Aksu, 2018, s. 177)

Yukarıda kuytu kelimesini kullanan şair, bu sefer de tenha sözcüğünü seçer. Kırık dökük sevdalar, sırlar tenhalarda dilsiz bir şekilde demlenmektedir. Burada demlenmek içki içmek anlamında kullanılmıştır. Şiirin tamamına sinmiş bir akşam kızıllığı vardır. İleriki dizelerde şu mısra karşımıza çıkar: "Yansıdı cama kırmızı bir hüzün.”

"Denizim içimde, rüzgârımın gülü yok

Bir ben seferde, başka yolcu yok

Yansıd cama kırmızı bir hüzün

Bir güvertede okuldan dönüşüm

Yüreğim güvercin, vakit alacakara

Rastgele deli gönül hatıralara" (Aksu, 2018, s.177)

Şair, akşam oldu demek yerine akşamın kızıllığının cama yansıdığını belirterek sanatlı bir söyleyişe gider:

"Bireysel anlamda kendini bir sıkışmışlık ve huzursuzluk içerisinde hisseden Haşim, fiziksel çirkinliğinin de etkisiyle sürekli hayal dünyasına sığınma ihtiyacı hisseder. İç dünya ile dış dünya arasında bir iç huzursuzluk yaşayan Haşim, kendinden hareketle çevresinden de nefret eder ve kaçar hale gelir. Bu nedenle gerçeğin kaba görüntüsünün daha net çizgilerle belirgin olduğu gündüzler yerine akşamı ve karanlığı sever. Bunun yansıması olarak da gerçekliğin dışına hayaller dünyasına yönelir. Fakat hayaller ile gerçekler arasındaki çatışma, bireyin fiziksel durumunu trajik bir biçimde belirler." (Kanter, 2011, s. 970)

Aksu'nun şiirindeki bütün bu benzetmeler ve söyleyişler bize onu ve şiirini çağrıştırır.

Sadece yukarıdaki şiirde değil, 1996' da yazdığı Zalim adlı eseri de okuyucuya Ahmet Haşim'i hatırlatır. Bilindiği gibi Ahmet Haşim'in Merdiven isimli şiiri şu şekildedir:

Ă̆ır ă̆ır çılkacaksın bu merdivenlerden

Eteklerinde güneş rengi bir ylğın yaprak

Ve bir zaman bakacaksin semaya ağlayarak... 
Sular sarardl... yüzün perde perde solmakta

Kızıl havaları seyret ki akşam olmakta ...

Eğilmiş arza, kanar, muttasıl kanar güller

Durur alev gibi dallarda kanlı bülbüller

Sular mı yandl, neden tunca benziyor mermer?

Bir lisan-ı hafidir ki ruha dolmakta

Kızıl havaları seyret ki akşam olmakta... (Ahmed Haşim, 2004, s. 27)

Aksu'nun şiirinin daha ilk mısralarında, Ahmet Haşim'i hatırlatan ifadeler yer alır. Seçtiği kelimelere dikkatle bakıldığında yukarıdaki şiirle benzerliği iyice ortaya çıkar:

"Ten beyaz, saç kızll güller

Kahkahasında bülbüller

Kirpiği kapkara tüller

Ben o afete vuruldum" (Aksu, 2018, s. 180)

Sezen Aksu'nun mu mısralarıyla, Merdiven şiirinin "güller, bülbüller ve mermer" diye biten mısraları karşılaştıııldığında hem seçilen kelimeler hem de kafiye ve ahenk açısından ne kadar benzedikleri görülür. Şiirin üçüncü dörtlüğünde Ahmet Haşim'de de sıkça karşımıza çıkan ve Haşim'in sevdiğini bildiğimiz "gölge" mefhumu yer alır. Aksu, gölgesini yanına alıp hasretin yoluna vurmuştur:

"Gölgemi aldım yanıma

Vurdum hasretin yoluna

Benzedim bahtsiz mecnuna

Yüce Mevla'ya slğındım"

Şiirin dördüncü kısmı ise doğrudan Merdiven şiiriyle alakalıdır. Haşim, bu bir gizli dildir ki ruha dolmakta, kızıl havaları seyret ki akşam olmakta diyordu. Sezen Aksu ise

"Seyret perişan halimi

Bende akşam olmakta

Dostlar seyrelmis,

Beyhude lafla vakit dolmakta" (Aksu, 2018, s.180)

demeyi tercih eder. Bu şiiri Merdiven'den ayıran en önemli nokta ise sitem ve serzeniş barındırmasıdır. Sevgilisini "kara vicdanlı yâr" olarak niteleyen şair, şiirin sonunda daha da ileri giderek sevdiğine "zalim" der ve daha önce sorduğu "Senin Allah'ın yok mu?" sorusuna, yine kendi cevap veriri: "Senin Allah'1n yok."

\section{3- Konu Bakımından Benzerlikler}

Sezen Aksu'nun, "ölümden ve yaşlanmaktan duyulan korku" konusunu anlatan şiirlerinden ilki 1982 yılında yazdığı Neredesiniz'dir ${ }^{8}$. Korkusunu açıkça ifade ettiği bu şiirdeki konuyu, ileriki yıllarda da işlemeye devam edecektir. Sezen Aksu'nun ölüm ve yaşl1lık endişesini gördüğümüz bu şiirler bize, Cahit

\footnotetext{
${ }^{8}$ Mümtaz Sarıçiçek makalesinde, Sezen Aksu'nun bu şiirini sone tarzına benzer bir mısra kümelendirmesi yaparak yazdığını ifade etmiştir. (Sarıçiçek, 2004, s. 29)
} 
Sitkı'yı hatırlatmaktadır. Cahit Sıtkı'da ölüm temasının ne denli sık işlendiği bilinmektedir. Aksu'nun şiiri okununca akla Otuz Beş Yaş şiiri gelmektedir:

"Erken geldi o mevsim

\section{Zamandan korkuyorum}

Bu beyazlar yaşım değil,

Yaşadıklarımdan iz" (Aksu, 2018, s. 202)

Yüzdeki değişim, çizgilerin oluşması, gözlerin yanında, hatta dudakların kenarındaki izler; yani çizgiler şaire yabancı gelmektedir. Onları tanıyamaz ve nereden, nasıl çıktıklarını anlamaya çalışır:

"Sevgiler, sevgililer, özlemler, ayrllıklar,

Kavgalar, çelişkiler kalır mı çizgisiz?

Gözlerimin yanında, bir zaman dudağımda

Olmayan izler, kimsiniz?" (Aksu, 2018, s.202)

Cahit Sıtkı da Otuz Beş Yaş şiirinde yüzündeki bu değişimden bahsetmiştir. Kendini tanıyamaz. Eski resimlerdeki adamla hiçbir ilgisi yoktur:

"Zamanla nasıl değişiyor insan!

Hangi resmime baksam ben değilim.

Nerde o günler, o şevk, o heyecan?

Bu güler yüzlü adam ben değilim;

Yalandır kaygısız olduğum yalan." (Taranc1, 2014)

Sezen Aksu, bu şiiri yazdığında yirmi sekiz yaşındadır. "Yolun yarısı"nın otuz beş olduğunu kabul etmiştir. Bu yüzden, daha yolun yarısına bile gelmeden yaşadığı değişime isyan eder:

"Yolun yarısı bile değilken

Ylllar beni nasil geçtiniz

Hâlâ umutlarla uyanırken

Gençliğime çizgi çektiniz" (Aksu, 2018, s. 202)

Bilindiği gibi, yolun yarısının; yani ömrün yarısının otuz beşinci yaş olduğu tespiti Cahit Sıtkı tarafından şiirinde yapılmıştır. Sezen Aksu da kendi şiirinde buna gönderme yapmış olur:

"Yaş otuz beş! Yolun yarısı eder.

Dante gibi ortasındayız ömrün.

Delikanlı çağımızdaki cevher

Yalvarmak yakarmak nafile bugün,

Gözünün yaşına bakmadan gider.” (Taranc1, 2014)

Sezen Aksu'nun şiirinin son dörtlüğündeki ifadeler ise bize Oğuz Atay’ın Korkuyu Beklerken isimli hikâye kitabındaki Demiryolu hikâyecileri-bir rüya adlı öykünün o meşhur son cümlesini hatırlatır. Bilindiği gibi hikâye, "Ben buradayım sevgili okuyucum, sen neredesin acaba?" cümlesiyle biter. (Atay, 2008, s.196) Sezen Aksu ise şiirinin son dörtlügünde benzer bir şekilde dostlarına ve sevgililerine şöyle seslenir: 
"Hani o çok sevenler

Ey dostlar, sevgililer

Ben buradayım,

Ya siz neredesiniz?" (Aksu, 2018, s. 202)

Kurşuni Renkler, Sezen Aksu tarafından 1985 yılında, kendisi otuz bir yaşındayken yazılmış bir şiirdir. Şiirin tamamı okununca yine Cahit Sıtkı Tarancı'nın Otuz Beş Yaş isimli eserinde işlenen konunun burada da olduğu görülür:

"Bir sabah saçlarımı okşayıp da rüzgâr

İzlerini sürüp de gidecek beyaz beyaz

Ve güneş aynaya baktı̆̆ımda

Çizgilerden yeni bir yüz gösterecek üzülerek biraz” (Aksu, 2018, s.184)

Şairin saçlarındaki beyazlı̆̆ın tek sebebi yaşlılıktır. Ancak burada, saçlardaki beyazlığın sebebi, rüzgâra bağlanmıştır. Güya, sabahleyin şairin saçlarını rüzgâr okşamışırı; yani saçları rüzgârda savrulmuştur. $\mathrm{Bu}$ rüzgâr da saçlarına beyaz beyaz izlerini sürüp gitmiştir. Buna benzer bir durumu Otuz Beş Yaşs şiirinde görürüz:

"Şakaklarıma kar mı yă̆dı ne var?

Benim mi Allah'im bu çizgili yüz?

Ya gözler altındaki mor halkalar?

Neden böyle düşman görünürsünüz,

Yillar yılı dost bildiğim aynalar?" (Taranc1, 2014)

Tarancı'nın şiirinde ise saçlarındaki beyazları karın marifetiymiş gibi görme vardır. Buradaki "ayna", "çizgi" ve "yüz" mefhumları, Aksu'nun şiirinde de yer alır. Her ikisi de aynaya bakar. İkisinin de gördüğü yüzlerindeki çizgilerden ibarettir. Ancak Tarancı'nın şiirinden bir teslimiyet ve razı oluş varken Aksu'nun eserinde isyan ve başkaldırı vardır:

"Yok olamaz dur, dur gidemezsin

Gözlerimin rengi dur, bulutlara dönemezsin

Yok alamazsin beni deli zaman, dur

Ömrüme o kurşuni renkleri süremezsin" (Aksu, 2018, s. 184)

Tarancı da pek çok şeyin renginin değiştiğinin farkındadır. Ancak bunu Aksu kadar dert etmeden bir kabullenişle ifade eder:

“Gökyüzünün başka rengi de varmış!

Geç fark ettim taşın sert olduğunu

Su insanı boğar, ateş yakarmış!

Her doğan günün bir dert olduğunu,

İnsan bu yaşa gelince anlarmış.” (Taranc1, 2014)

Her şeye rağmen, her iki şair de ölüm gerçeğinin farkındadır. O gün geldiğinde neler olacağının bilincindedirler, ancak Sezen Aksu ölmek istemediğini yalvararak ifade eder: 
"O gün başka renkte ağaracak biliyorum

Ve zorla değil ya, o rengi hiç sevmiyorum

Ne olur sanki biraz daha zaman verseniz

Yıllar öfkenizi hiç mi hiç anlamıyorum" (Aksu, 2018, s. 184)

Cahit Sıtkı ise bu duruma daha farklı bir bakış açısıyla yaklaşır. Evet, ölüm gerçektir, ancak bir de bardağın dolu tarafina bakmak gerekir:

"N'eylersin ölüm herkesin başında

Uyudun uyanamadin olacak.

Kimbilir, nerde, nasıl, kaç yaşında?

Bir namazlı saltanatın olacak.

Taht misali o musalla taşında" (Taranc1, 2014)

\section{D- MÜSTAKİL BİR ŞEKİLDE ELE ALINMASI GEREKEN BİR ŞIIIR: RAKKAS}

Sezen Aksu, kimi şiirlerini tek başına kaleme almamış, başka kişi veya kişilerce ortaklaşa yazmıştır. Bu tip şiirlerini Aksu, her iki kitabına da almamıştır. Bunlardan, konumuz açısından en dikkat çekenlerinden biri ise Yelda Karataş ile birlikte kaleme aldığı ve 1995 yılında çıkardığı Işık Doğudan Yükselir isimli albümünde şarkı olarak yer alan Rakkas adlı şiirdir. Mümtaz Sarıçiçek, bu şiirin eğlence dünyasına yönelik bir eleştiri olduğunu ifade etmiştir. Vurgun ve talanlarla kolay yoldan kazanılan paraları, barlarda ve tavernalarda saçıp savuran insanları eleştirmek amacıyla yazıldığını kaydeder (Sarıçiçek, 2004, s. 36).

Rakkas geldi meydane

Al bastl ak gerdane, ay canlar

Böyle dilber gördün mü?

Ey meclis-i şahane, ay canlar

Aşk ile Allah Allah

Vur tefe, vur zile yallah

Cihan da böyle yanıyor, yansin

Yosmam salla

Bu dem talan çağıdır

Yer ki meram bağıdır, ay canlar

Sen kivır, çevir rakkas

Bu hal dünya halidir, ay canlar

Salla salla

Gül memeler çağlasın

Salla salla

Yer yerinden oynasın ${ }^{9}$

\footnotetext{
${ }^{9}$ https://www.youtube.com/watch?v=LYDOlK-wSX0
} 
Bu şiirde seçilen kelimeler dikkat çekicidir. Şiir, öncelikle bir divan şiiri gibi başlar. Mesela, kullanılan "raks" kelimesi divan şiirinde de vardır:

“Oyun, sıçrayarak oynama. Eski dönemlerin raksı günümüzün danslarına benzemezdi. Köçek denilen rakkaslar tarafindan oynanan efeleme, zeybek, horan vs. oyunlar raks olarak nitelendirilirdi. Belki Yahya Kemal'in Endülüs'te Raks adlı şiirinde anlattı̆g İspanyol fiestalarına raks denebilir. Divan şiirinde raks bir neşe alameti olarak görülür." (Pala, 2003, s. 387)

Şiirdeki gerdan, dilber gibi kelimeler de divan şiirinden alışı olduğumuz ifadelerdir. Bunun yanı sıra üslup açısından düşünürsek şiirde "meclis-i şahane" gibi Farsça tamlamalar dahi kullanılmıştır. Kısacası şiir bir divan şiiri havasıyla başlar; fakat daha sonra sanki bir tekke ortamımış gibi "def, zil ve Allah" kelimelerinin geçtiği bir bölüm gelir. Bu kısımda şiir, neredeyse bir tekke şiirine dönüşür. Son kısımda ise daha da garipleşir ve bu sefer tıpkı Garip şiirinde olduğu gibi, aykırı kelimelerin şiire girdiği görülür. Bu kelimeler "yosma" ve "meme" kelimeleridir. Şiire bütünüyle baktığımızda bir geçişkenlik olduğunu görmekteyiz. Bu açıdan şiir bizi şaşırtır. Eserde divan ve halk şiirinin yanında modern şiirin de izlerinin olduğu görülmektedir.

\section{SONUÇ}

Yetmişli yıllardan beri Türk insanı tarafından dinlenen Sezen Aksu, her zaman söylediği şarkılarla etkileyici bulunmuştur. Onun şarkılarıyla kimi zaman yüreği titreyen kimi zaman da şenlenen insanlar özellikle, onun eserlerindeki sözlere dikkat çekmişler ve ne kadar etkileyici olduklarını dile getirmişlerdir. Sezen Aksu dört yüzden fazla şarkı sözünü sadece kendisine saklamamış, pek çok sanatçıya bu sözleri vermiş, onların da bu etkileyici sözleri söyleyebilmelerine izin vermiştir. Sanatçının şarkılarındaki bu sözleri, basit birer şarkı sözünden çok daha ötede görmekteyiz. Bu çalışmanın sonunda, her şark1 sözünün şiir olamayacağını, bir şarkı sözüne "şiir" diyebilmek için onun çok daha fazla özellik taşıması gerektiği anlamış durumdayız. Bu noktada, gelenekten beslenme ve yararlanma kesinlikle en önemli unsur olarak görülmelidir.

Sezen Aksu'nun şiirlerinin bu kadar etkili olmasındaki sebeplerden biri de onun, gelenekten yararlanmasını bilmesidir. Şair, pek çok şeyden beslenmiş, kendisini sadece bir alana kapatmamıştır. Şiirlerinde divan edebiyatından izler bulmamız, onun zihninde bu edebiyatın mazmunlarının bir şekilde yer etmiş olduğunu gösterir. Sezen Aksu'nun kimi şiirleri okunduğunda okuyucunun zihninde, divan edebiyatındaki bazı mazmunlar çağrışım yapar. Divan şiirindeki çoğu mazmunu, şiirlerinde çok güzel bir şekilde kullanması dikkat çekicidir. Kendisi bu mazmunları, okuyarak zihnine yerleştirmiş olabileceği gibi sadece dinleyerek de öğrenmiş olabilir. Aksu, yalnızca divan şïiriyle yetinmemiş, kapılarını halk edebiyatına da açmıştır. Ninni, türkü, ağıt gibi halk şiirinin önemli türlerini hatırlatan eserler veren şair, bunları modern hayata uydurmayı da bilmiştir. Onun beslendiği kaynaklardan biri de Cumhuriyet Dönemi ve sonrasında gelişen edebiyattır. Ahmet Haşim'den Cahit Sitkı'ya; Yaşar Kemal'den Oğuz Atay'a; Ahmet Arif'ten Turgut Uyar’a kadar onun şiirinde pek çok şairden gizli ya da açık izler vardır. Bütün bunlar, sanatçının ne kadar geniş bir kültür yelpazesinden beslendiğini ortaya koyar.

$\mathrm{Bu}$ çalışmadaki tespitler, edebiyat araştırmacısının bilgi birikimine ve vâkıf olduğu alanlara göre yapabildiği saptamalardır. Bu bilgi birikimine göre şiirler okunduğunda zihne gelen çağrışımlar / ihtimaller araştırmada paylaşılmıştır. Elbette ki farklı alanlara vâkıf bir başka araştırmacının bu şiirleri okumasıyla bambaşka tespitler ortaya çıkabilir. Dolayısıyla, bu araştırmadaki saptamalar edebiyat araştırmacısının kişisel okuma serüveninin bir ürünüdür ve okuma dağarcığının ne kadar geniş olduğu ile ilgilidir. Bu sebeple, Sezen Aksu'nun şiirleri farklı okuma dağarcıklarına sahip araştırıcılar tarafından, başka bakış açılarıyla okunup tekrar tekrar değerlendirilmeye müsaittir. 


\section{KAYNAKÇA}

Ahmed Haşim (2004). Piyale. haz. Sabahattin Çağın. İstanbul: Çağrı Yayınları.

Aksu, S. (2016). Eksik şiir ikinci kitap. İstanbul: Metis Yayınları.

Aksu, S. (2018). Eksik şiir. İstanbul: Metis Yayınları.

Atay, O. (2008). Korkuyu beklerken. İstanbul: İletişim Yayınları.

Aydoğan, B. (2005). Bedri Rahmi Eyuboğlu'nun şiirlerinde meyvelerin önemi ve kullanılışı. Çukurova Üniversitesi Sosyal Bilimler Enstitüsü Dergisi, 14(1), 85-106.

Çelebioğlu, A. (1987). Ninnilerimiz. Erdem, 3(7), 211-238.

Ecevit, H. (2018). Attilâ Illhan'ın şiirlerinde kadın. Yayımlanmamış yüksek lisans tezi, Trakya Üniversitesi, Edirne.

Elçin, Ş. (2000). Halk edebiyatına giriş. Ankara: Akçağ Yayınları.

Feyzioğlu, N. (2010). Gelin ağıtları üzerine bir değerlendirme. Atatürk Üniversitesi Türkiyat Araştırmaları Enstitüsü Dergisi, 17(43), 73-92.

Gariper, C. (2002). Karacaoğlan'dan Sabahattin Ali’ye tevekkülün ve başkaldırının şiiri. İlmî Araştırmalar, (14), 61-72.

Göde, H. A. (2010). Kına türküleri üzerine. Folklor/Edebiyat, (64), 163-180.

Gözaydın, N. (1989). Anonim halk şiiri üzerine. Türk Dili, ( 445-450), 1-104.

Kanter, M. F. (2011). Tevfik Fikret ve Ahmet Haşim'in şiirlerinde ütopya. Turkish Studies, 6(3), 963972.

Koşar, E. (2010). Bedri Rahmi Eyüboğlu'nun Karadut şiirinde halk kültürü izleri. Mimar Sinan Güzel Sanatlar Üniversitesi Sosyal Bilimler Enstitüsü Dergisi, (2), 81-88.

Mirzaoğlu, F. G. (2019). Gurbet türkülerinde İstanbul imgesi: ‘yârim İstanbul'u mesken mi tuttun?'. Folklor/ Edebiyat, 25(100), 849-859.

Özger, M. (2011). Turgut Uyar şiirinde denge metaforu. Trakya Üniversitesi Edebiyat Fakültesi Dergisi, 1(2), 131-142.

Pala, İ. (2003). Ansiklopedik divan şiiri sözlüğü. İstanbul: Leyla ile Mecnun Yayıncılık.

Sarıçiçek, M. (2004). Şair Sezen Aksu. Türk Dili Dil ve Edebiyat Dergisi, LXXXVIII(631), 26-36.

Sarıçiçek, M. (2018). Şair Sezen Aksu müziğin gölgesindeki şiir. Kayseri: Kimlik Yayınları.

Sefercioğlu, M. N. (Tarihsiz). Nev'î divanının tahlili. Ankara: Akçağ Yayınları.

Tarancı, C. S. (2014). Otuz beş yaş: bütün şiiirleri. İstanbul: Can Yayınları.

Uludağ, M. E. (2013). Ahmet Arif' in şiirlerinde Anadolu sevgisinin yansımaları. Atatürk Üniversitesi Türkiyat Araştırmaları Enstitüsü Dergisi, (49), 203-210.

\section{İnternet Siteleri}

https://www.youtube.com/watch?v=8cE6UcXWJ4I

https://sozluk.gov.tr/

https://www.youtube.com/watch?v=LYDOlK-wSX0 